Table I Determination of chlorine

\begin{tabular}{|c|c|c|c|}
\hline \multicolumn{2}{|c|}{ Sample } & Found $(\%)$ & Error $(\%)$ \\
\hline \multirow[t]{2}{*}{ DDT } & \multirow[t]{2}{*}{$50.00 \%$} & $\begin{array}{l}49.75 \\
49.52 \\
49.37 \\
49.75\end{array}$ & $\begin{array}{l}-0.50 \\
-0.96 \\
-1.26 \\
-0.50\end{array}$ \\
\hline & & Av. 49.71 & \\
\hline \multicolumn{2}{|c|}{$\begin{array}{l}\text { Polyvinyl } \\
\text { chloride } \\
56.73 \%\end{array}$} & $\begin{array}{l}56.70 \\
56.81 \\
56.97 \\
56.66\end{array}$ & $\begin{array}{l}-0.05 \\
+0.14 \\
+0.42 \\
-0.12\end{array}$ \\
\hline \multirow{3}{*}{$\mathrm{BHC}$} & \multirow{3}{*}{$73.14 \%$} & Av. 56.79 & \\
\hline & & $\begin{array}{l}72.62 \\
72.55 \\
72.37 \\
72.95\end{array}$ & $\begin{array}{l}-0.71 \\
-0.81 \\
-1.05 \\
-0.26\end{array}$ \\
\hline & & Av. 72.62 & \\
\hline
\end{tabular}

Table II Determination of chlorine

\begin{tabular}{|c|c|c|}
\hline Sample & Found $(\%)$ & Error (\%) \\
\hline $\begin{array}{l}\text { Monochloro } \\
\text { benzene } \\
31.50 \%\end{array}$ & $\begin{array}{l}31.17 \\
31.32 \\
31.34 \\
31.22\end{array}$ & $\begin{array}{l}-0.33 \\
-0.18 \\
-0.16 \\
-0.28\end{array}$ \\
\hline \multirow[t]{2}{*}{$\begin{array}{c}p \text {-Chloroaniline } \\
27.79 \%\end{array}$} & $\begin{array}{r}\text { Av. } 31.26 \\
\\
27.64 \\
27.57 \\
27.65 \\
27.72\end{array}$ & \multirow[t]{2}{*}{$\begin{array}{l}-0.54 \\
-0.79 \\
-0.51 \\
-0.26\end{array}$} \\
\hline & Av. 27.65 & \\
\hline
\end{tabular}

みると，フラスコ法では高分子化合物でも容易に分解す ることができるが，試料が液状のときはカプセルに入れ るなどの考慮が扛われねばならない，また，液安法は高 分子化合物の分解には適しないが，試料が液状であって も操作は変わりなく，多数の試料を同時に分解する場合 に特に有利であるといえよう。

分析に要する時間は滴定を含めて, フラスコ燃焼法で
は約 $30 \sim 40$ 分，液体アンモニアー金属ナトリウム法で は約 20 分であった. この所要時間は分解の操作法を検 討2)することによって，さらに短縮することができると 考えられる.

この研究を行なうにあたって, 適切な御指導を賜わっ た横浜国立大学工学部河村文一教授ならびに本学荒木峻 教授に深く感謝致します.

(1960 年 6 月, 分析化学討論会にて一部講演)

\section{文 献}

1) W. Schöniger : Mikrochim. Acta, 1955, 123.

2）荒木 峻，鈴木繁喬，小林英吾：日本分析化学会 第 9 年会講演 (1960 年 11 月).

3) Chem. Eng. News, 37, No.14, 34 (1959).

4) 鈴木繁喬 : 本誌, 11, 228 (1962).

is

Determination of chlorine in organic compounds with coulometric titration. (Coulometric titration with externally generated silver ion. II.) Shigetaka Suzuki (Faculty of Technology, The Tokyo Metropolitan University)

Coulometric titration with externally generated silver ion was successfully applied to the determination of chlorine in organic compounds.

Organic compounds were decomposed either with combustion in oxygen-filled Schöniger's flask or with liquid ammonia and metallic sodium. After the decomposition, chloride ion was titrated coulometrically with externally generated silver ion using the same procedure as reported previously by the author $\{\mathrm{S}$. Suzuki : this journal, 11, 228 (1962)\}.

The determination of chlorine was carried out with good results as shown in Table I or II after the decomposition either with Schöniger's method or with liquid ammonia and sodium, respectively.

(Received Oct. 10, 1961)

\title{
イオン交換クロマトグラフィーによるベルベリンと アトロピン，スコポラミンとの分離
}

\author{
渡辺兵 蔵**
}

弱酸性陽イオン交換樹脂（Duolite CS-101，100〜200 メッシュ）の $\mathrm{NH}_{4}$ 形のカラムを用い，試料 に塩酸ベルベリン，硫酸アトロピン打よび臭化水素酸スコポラミンを用いて，水觉溶離㓮としてスコポ ラミン㟒，塩化アンモ二ウム $(0.2 N)$ でアトロピン范,炭酸ナトリウム $(1 N)$ でベルベリンを溶離し， 三者分分傩することができた。ただし，アトロピンとスコポラミンの回收率はやや不良であった。

* 医薬品分析に扣けるイオン交換樹脂の応用(第 7 報) $\quad * *$ 山形県立山形工業高等学校 : 山形市緑町 


\section{1 緒言}

前報》においてイオン交換クロマトグラフィーによる ベルベリンとストリキニンの分離について述べたが，今 回は同様な方法によりベルベリンとアトロピン，スコポ ラミンの分離について報告する。

アトロピンとスコポラミンとの分離については, Freeman ${ }^{2)}$ 酸化繊維素をイオン交換郕として分離し ており, 吉野ら ${ }^{3)}$ は弱酸性陽イオン交換樹脂 (Duolite CS-101， H 形 $+\mathrm{Li}$ 形， Li 形が約 15\%) を用い，塭 化りチウムと塩化カリウムを溶離剂として両者を分離し ている。また，山口ら4) は口紙電気泳動法によりアトロ ピンとスコポラミンを分離後, Freeman 法5により発 色させて吸光度を測定し，両者を定量している。このよ うにアトロピンとスコポラミンとの分離についてはかな り研究されているが，これらのアルカロイドとベルベリ ンとの分離については今のところ報告は見当らない。

著者注弱酸性陽イオン交換樹脂 (Duolite CS-101) の $\mathrm{NH}_{4}$ 形を用いて，水を溶離郕としてスコポラミンを 塩化アンモニウムでアトロピンを, 炭酸ナトリウムでベ ルベリンを溶離後, ケイタングステン酸を沈殿試薬とす る電流滴定法によりこれらのアルカロイドを定量した.

\section{2 実験方法}

\section{$2 \cdot 1$ 実験試料}

塩酸ベルベリン:オウバク皮（角約 $1 \mathrm{~cm}$ ) を水酸化 カルシウム（原料の $20 \%$ ）水溶液で，室温で 24 時間抽 出したものをロ過し，口液塩化ナトリウム $(3 \% \mathrm{~W} / \mathrm{V})$ を加えてベルベリンを塩酸塩として沈殿させ，口取した 沈殿を水より再結晶し, さらにメタノールより 2 回再結 晶を繰り返して得た黄色針晶它，60〜 $65^{\circ} \mathrm{C}$ で恒量にな るまで乾燥したのち，一部をとり約 $2 \mathrm{mg} / \mathrm{ml}$ 水溶液と 乙て用いた。融点 (分解) $204 \sim 205^{\circ} \mathrm{C}$, 実験值 C 58.69 $\%, \mathrm{H} 5.68 \%, \mathrm{~N} 3.61 \%, \mathrm{C}_{20} \mathrm{H}_{18} \mathrm{O}_{4} \mathrm{NCl}-2 \mathrm{H}_{2} \mathrm{O}$ として の計算值 C $58.90 \%, \mathrm{H} 5.44 \%, \mathrm{~N} 3.44 \%$.

実際の濃度はケイタングステン酸を沈殿試薬として電 流滴定法胡によって決定した。

硫酸アトロピン: 局方品を $110^{\circ} \mathrm{C}$ で 4 時間乾燥した のち, 約 $1 \mathrm{mg} / \mathrm{ml}$ の水溶液として用いた. 実際の濃 度は電流滴定法》によった。

臭化水素酸スコポラミン：局方品（ドイツ製）を 105 ${ }^{\circ} \mathrm{C}$ で 4 時間乾燥したものを, 約 $1 \mathrm{mg} / \mathrm{m} l$ 水溶液とし て用いた. 純度は非水滴定法 (U. S. P.VI) によって 決定したが，分離のさいは電流滴定法》によった。 な㞧，試薬の濃度を一括して Table I に示した。
イオン交換樹脂 : 弱酸性陽イオン交換樹脂 Duolite CS-101（100〜200 メッシュ）の Na 形および $\mathrm{NH}_{4}$ 形 を使用した．処理方法注前法と同様である。

Table I Concentration of reagents

\begin{tabular}{llcc}
\hline \multicolumn{1}{c}{ Alkaloids } & \multicolumn{1}{c}{$\begin{array}{c}\text { Molecular } \\
\text { formulae }\end{array}$} & $\begin{array}{c}\text { Results } \\
(\mathrm{mg} / \mathrm{ml})\end{array}$ & $\begin{array}{c}\text { As free } \\
\text { base } \\
(\mathrm{mg} / \mathrm{ml} l)\end{array}$ \\
\hline $\begin{array}{c}\text { Berberine } \\
\text { hydrochloride }\end{array}$ & $\mathrm{C}_{20} \mathrm{H}_{18} \mathrm{O}_{4} \mathrm{NCl} \cdot 2 \mathrm{H}_{2} \mathrm{O}$ & 1.91 & 1.65 \\
$\begin{array}{c}\text { Atropine } \\
\text { sulfate }\end{array}$ & $\left(\mathrm{C}_{17} \mathrm{H}_{23} \mathrm{O}_{3} \mathrm{~N}\right)_{2} \cdot \mathrm{H}_{2} \mathrm{SO}_{4}$ & 0.92 & 0.79 \\
$\begin{array}{c}\text { Scopolamine } \\
\text { hydrobromide }\end{array}$ & $\mathrm{C}_{17} \mathrm{H}_{21} \mathrm{O}_{4} \mathrm{~N} \cdot \mathrm{HBr}$ & 0.84 & 0.67 \\
\hline
\end{tabular}

\section{$2 \cdot 2$ 分離操作}

硫酸アトロピン，系化水素酸スコポラミンおよび填酸 ベルベリンの各水溶液の一定量をピペットでとり，よく 混合してから約 $0.5 \mathrm{ml} / \mathrm{min}$ の流速でカラム $\left(\mathrm{NH}_{4}\right.$ 形, $8 \times 280 \mathrm{~mm})$ に通ずる.試料が全部通じ終ったら口液は 捨てないでとっておく（スコポラミンの一部がも机る場 合がある)。つぎに水でカラムを洗浄すると，スコポラ ミンが溶離してくる*. 流出液はサイフォンピペット (10 $\mathrm{m} l$ ) で分取し，その $1 \mathrm{~m} l$ をとり希塩酸を加えて微酸 性とし**，ケイタングステン酸試液（1\%）在加えてア ルカロイドの反応を呈しなくなるまで溶離をつゔけ，全 流出液を集成たのちつぎの溶離に移る。

スコポラミンの溶離が完了したら， $0.2 N$ の塩化アン モニウム水溶液を通ずると，流出液にはアトロピンが含 まれる、アトロピンの反応が呈しなくなったら，つぎに $1 N$ 炭酸ナトリウム水溶液にきりかえると, ベルベリン が黄色を呈して溶離してくる．各アルカロイドごとの流 出液を集め，その一部をとって電流滴定法によって各ア ルカロイドを定量した．ただし，溶離図作製の場合は 1 フラクションごとに定量した。

\section{3 実験 結果}

\section{$3 \cdot 1$ アトロピンとベルベリンの分離}

$\mathrm{Na}$ 形のカラムを用いて, アトロピンの溶離剂に塩化 ナトリウムを，ベルベリンの溶離剂に炭酸ナトリウムを 用いた場合の溶離の状態を Fig. 1 亿示した, 最初 0.5 $N$ の塩化ナトリウム水溶液を通ずると, $0 \sim 60 \mathrm{ml}$ の間 にアトロピンが溶離されてくる，アトロピンが検出され

*スコポラミンは水で溶離されるが，アトロピンは水

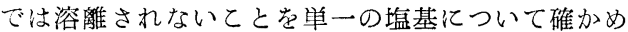
てある。

** 塩酸濃度が高いと沈殿が溶解するから 注意を 要す る。 
なくなったら，少量の水で洗ったのち $1 N$ 炭酸ナトリ ウム水溶液㱏通ずると, 流出液の $140 \mathrm{~m} l$ 付近からベル ベリンが黄色を呈して溶嶉してくる.

つぎに $\mathrm{NH}_{4}$ 形のカラムを用いて分離した例をFig. 2 に示した。この場合にはアトロピンの溶離剤には塩化ア ンモニウム $(0.2 N)$ を，ベルベリンの溶離剂には同じ く炭酸ナトリウム $(0.5 N)$ 学使用した.

このようにアトロピンとベルベリンと注，Na 形また は $\mathrm{NH}_{4}$ 形のカラムを用いて分離することができる。そ の結果を Table II (No. 1,2) に示した.

なお，H形のカラムを用いた場合は，アトロピンは酸 による溶離は容易であるが, ベルベリンは困難であるの でこの場合はむしろ $\mathrm{Na}$ 形や $\mathrm{NH}_{4}$ 形の方が適当で ある。

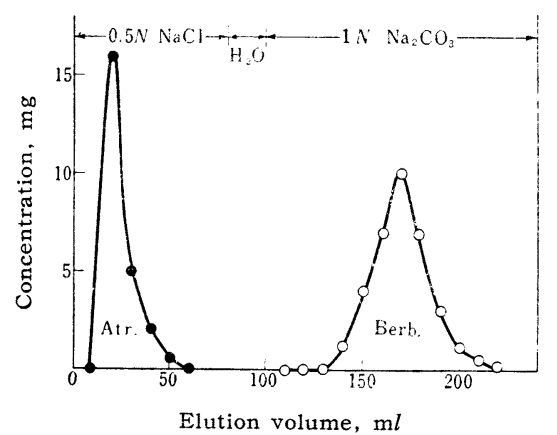

Fig. 1 Elution diagrams of atropine and berberine (I)

Duolite CS-101, Na form

Column $8 \times 360 \mathrm{~mm} \quad$ Flow rate $1.0 \mathrm{ml} / \mathrm{min}$

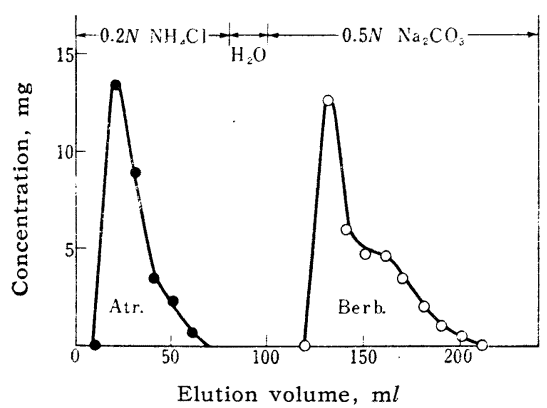

Fig. 2 Elution diagrams of atropine and berberine (II)

Duolite CS-101, $\mathrm{NH}_{4}$ form

Column $8 \times 225 \mathrm{~mm}$ Flow rate $0.45 \mathrm{~m} ! / \mathrm{min}$

\section{$3 \cdot 2$ スコポラミンとベルベリンの分離}

$\mathrm{NH}_{4}$ 形のカラムにスコポラミンとベルベリンを含さ
水溶液を通ずると，スコポラミンの一部没吸着の過程で すでにもれてくる.つぎにカラムを水洗すると，樹脂中 に残っているスコポラミンは溶離してくる. 溶出液の一 部孛とりスコポラミンが検出されなくなってから， 0.2 $N$ の塩化アンモニウム水溶液を通じても，スコポラミ ンはほとえど検出されなかった。このような現象注 $\mathrm{Na}$ 形のカラムを用いても同様で，スコポラミンは水により 溶離してくることがわかった． $\mathrm{NH}_{4}$ 形のカラムを用い た場合の溶離の状態を Fig. 3 に示した。また，分離例 を Table II (No. 3,4) に示した.

このようにスコポラミンとベルベリンの分離には, $\mathrm{NH}_{4}$ 形または $\mathrm{Na}$ 形のカラムを用いて, 水を溶離剂と してスコポラミンを，炭酸ナトリウムでベルベリンを溶 離して両者を分離することができる.

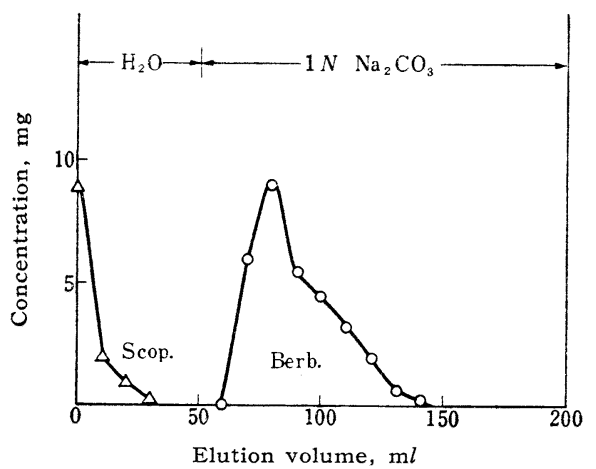

Fig. 3 Elution diagrams of scopolamine and berberine

Duolite CS-101, $\mathrm{NH}_{4}$ form

Column $8 \times 255 \mathrm{~mm}$ Flow rate $0.5 \mathrm{ml} / \mathrm{min}$

\section{$3 \cdot 3$ スコポラミン, アトロピン, ベルベリンの分離}

これまでの実験結果を参考にして，スコポラミン，ア トロピンおよびベルベリンの分離を試みた。 $\mathrm{NH}_{4}$ 形の カラムを用いて分離した場合の溶離の状態を Fig. 4 に 示した.この場合もスコポラミンは吸着の過程でかなり もれてくることがわかった. カラム中残存しているス コポラミンは水で溶離してから， $0.2 N$ 塩化アンモニウ ムに切りかえると, アトロピンが溶離してくる. 溶出液 の一部をとりアトロピンが検出されなくなったら， $1 N$ の炭酸ナトリウム它通ずると, 最後にベルベリンが溶離 してくる. 分離の成績を Table II (No. 5〜7) 亿示し た.

以上のように水, 塩化アンモニウム拉よび炭酸ナトリ ウムを溶離剂として三者を分離できるが，アトロピンと スコポラミンの回収率はやや不良であった。 
Table II Recovery test for scopolamine, atropine, and berberine

\begin{tabular}{|c|c|c|c|c|c|c|c|c|c|}
\hline \multirow{2}{*}{$\begin{array}{c}\text { Expt. } \\
\text { No. }\end{array}$} & \multicolumn{3}{|c|}{ Samples used (mg) } & \multicolumn{3}{|c|}{ Detected alkaloids (mg) } & \multicolumn{3}{|c|}{ Recovery $(\%)$} \\
\hline & Scop. & Atr. & Berb. & Scop. & Atr. & Berb. & Scop. & Atr. & Berb. \\
\hline $1 \dagger$ & & 20.1 & 33.0 & & 16.4 & 30.0 & & 81.5 & 91.0 \\
\hline 2 & & 20.1 & 33.0 & & 17.8 & 31.5 & & 88.5 & 95.5 \\
\hline 3 & 13.4 & & 33.0 & 11.8 & & 32.4 & 88.0 & & 98.0 \\
\hline 4 & 13.4 & & 33.0 & 12.2 & & 32.7 & 91.5 & & 99.2 \\
\hline 5 & 13.4 & 15.8 & 41.4 & 11.1 & 13.8 & 40.7 & 82.5 & 87.5 & 98.5 \\
\hline 6 & 13.4 & 15.8 & 41.4 & 11.6 & 14.8 & 40.4 & 86.5 & 93.5 & 97.5 \\
\hline 7 & 16.8 & 19.8 & 33.0 & 15.4 & 18.5 & 32.9 & 91.9 & 93.5 & 99.7 \\
\hline
\end{tabular}

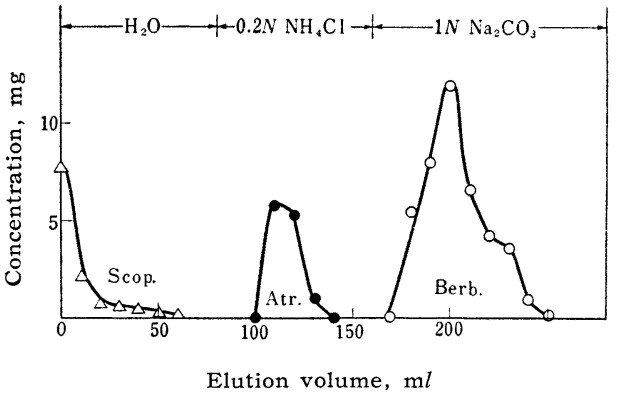

Fig. 4 Separation of scopolamine, atropine and berberine

Duolite CS-101, $\mathrm{NH}_{4}$ from

Column $8 \times 280 \mathrm{~mm}$ Flow rate $0.5 \mathrm{~m} l / \mathrm{min}$

\section{4 考察}

著者はベルベリンのイオン交換についての基礎研究を 行ない, カルボン酸型の弱酸性交換体の $\mathrm{NH}_{4}$ 形が最も 適していることを知った99. ベルベリンとアトロピン, スコポラミンを含さ水溶液を, 弱酸性交換体のカラム $\left(\mathrm{NH}_{4}\right.$ 形) に通じていったんこれらのアルカロイドを吸 着させた場合, スコポラミンは水で溶離されるが, アト ロピンは溶離されずまた，アトロピンは塩化アンモニウ ムで溶離されるが，ベルベリンは溶離されないことを利 用して三者を分離することができた。

アトロピンとスコポラミンとは同族体で構造が非常に よく似ているにもかかわらず，スコポラミンは水で溶離 されるが，アトロピンは溶離されないのは興味ある事実 である.スコポラミンの一部は吸着の過程ですでにもれ てくるが，その程度は実験觉始める前の樹脂の水洗が関 係するようである. そこで一定量の樹脂に対して水洗の 量をきめておくことがのぞましい.

吉野ら ${ }^{10}$ ) は有機塩基を弱酸性交換体に吸着させて, 水 による溶離を研究し, 力ラムを水で洗浄すると加水分解 のため流出液の $\mathrm{pH}$ 澍脂形によってことなり, 当然,
有機塩基の解離の状態に変化を与えることが予想され る. そして有機塩基の水による溶離の難易はその $\mathrm{pH}$ に おける解離状態と $K(\mathrm{~B} / \mathrm{M}) *$ （選択係数）によって決定 されることを推諭している. スコボラミンとアトロピン の場合も，カラムを水洗すると溶液層の $\mathrm{pH}$ に変化を 生じ, 両アルカロイドの解離状態ひいては $K(\mathrm{~B} / \mathrm{M})$ が 変化し，溶離されやすさに差を生ずるものと思われる.

アトロピンとスコポラミンとは水以外の溶離戍を用い た場合，ほとえど同時に溶離されて分離できなかった。 ただ，スコポラミンは水で溶離されるが， tailing の現 象が見られるところからすると，ごくわずかながら樹脂 中に残存するのではないかと思わ机る。そのほか，アト ロピンとスコポラミンの回収率が悪いのは定量誤差も考 えられる.アトロピンとスコポラミンの電流滴定は, 微 量の場合にはバラッキが大きくよい結果が得られなかっ た。

ベルベリンの回収率は比較的良好であり，ベルベリン とトロパンアルカロイドを分離することは容易である。

終りにのぞみ，本研究を助成された共立薬品工業株式 会社山崎正信社長，扣よび御指導をいただいた大阪市立 工業研究所吉野俊雄博士に深甚の謝意を表する.

\section{交献}

1) 渡辺兵蔵：本誌，10，271 (1961)。

2) F. M. Freeman : J. Pharm. and Pharmacol. 8, 42 (1956).

3) 吉野俊雄, 杉原瑞穂 : 薬誌，80，396 (1960).

4）山口一孝, 伊藤已代子 : 同上, 81, 179 (1961).

5) F. M. Freeman : Analyst, 80, 520 (1955).

6) 渡辺兵蔵 : 本誌, 10, 268 (1961).

7）小川忠彦：日化，77，540（1955).

8）渡辺兵蔵 : 未発表.

9）渡辺兵蔵：日化，82，461 (1961).

10) 吉野俊雄, 長柄 棓, 杉原瑞穂: 科工, 33,150 (1959).

论

* $K \frac{\mathrm{B}}{\mathrm{M}}=\left\{\frac{\mathrm{R} \mathrm{B}}{\mathrm{RM}}\right\}:\left\{\frac{(\mathrm{B})_{\mathrm{s}}}{(\mathrm{M})_{\mathrm{s}}}\right\}, \begin{aligned} & \mathrm{M} \text { は金属 } \\ & \mathrm{B} \text { は有機塩基 }\end{aligned}$ 
Separation of berberine, atropine, and scopolamine by ion exchange chromatography. (Application of ion-exchange resins in medicinal analysis. VII.) Hyozo Watanabe (Yamagata Technical High School)

Attempts have been made to separate berberine, atropine, and scopolamine by use of weak cationexchange resin (Duolite CS-101, 100 200 mesh).

An aqueous solution containing a mixture of berberine hydrochloride, atropine sulfate, and scopolamine hydrobromide was passed through a column of Duolite CS-101 $\left(\mathrm{NH}_{4}\right.$-form $)$ for ad- sorption of the alkaloids. A portion of scopolamine was eluted unadsorbed and the rest of it was liberated by washing the column with water. The column was then treated with $0.2 \mathrm{~N} \quad \mathrm{NH}_{4} \mathrm{Cl}$ for liberation of atropine and finally with $1 N$ $\mathrm{Na}_{2} \mathrm{CO}_{3}$ for liberation of berberine.

Each alkaloid thus liberated was determined by the amperometric titration.

The recovery was above $85 \%$ for atropine and scopolamine and above $95 \%$ for berberine.

(Received July 31, 1961)

\title{
Griess Romijn 試薬に対する新しい試み
}

\author{
萩 野堅*
}

(1) 抽出法: 試料溶液 $50 \mathrm{ml}$ K Griess Romijn 試薬（GR 試薬）を加えて発色させ, 次に塩酸 を加えて約 $1.5 \mathrm{~N}$ としブタノール・シクロヘキサノール (7:3) 混合溶媒 $10 \mathrm{ml}$ でてれを抽出して $0.002 \sim 0.07 \mathrm{ppm} \mathrm{NO}_{2}{ }^{-}-\mathrm{N}$ の超微量が感度よく定量できた。

（2）アルカリ添加法：中性の試料溶液に GR 試薬を加えて充分発色したのち，アルカリ溶液を加 えてアルカリ性にすると橙黄色の溶液が得られる。乙れを波長 $480 \mathrm{~m} \mu$ で吸光度を测定すれば $0.05 〜$ $1.0 \mathrm{ppm} \mathrm{NO}_{2}{ }^{-}-\mathrm{N}$ の定量ができる.

\section{1 緒司}

著者はさきに亚硝酸イオンの呈色試薬（Griess Romijn 試薬, 以下 $\mathrm{GR}$ 試薬という）に対する新しい試み としてェタノールの添加法1について報告した.

亚硝酸と GR 試薬によって生ずるアゾ色素がエタノ ールに可溶性であることから，上限の定量範囲が広げら れて $0.01 〜 0.35 \mathrm{ppm} \mathrm{NO}_{2}{ }^{-}-\mathrm{N}$ の榆量線が直線となつ た. 本報ではエタノールの代わりにブタノール・シクロ ヘキサノール混公溶媒を用いてこのアゾ色素を抽出する 方法について実験した.

種々検討の結果, 熄朘の濃度を約 $1.7 N$ として抽出 を行ない, 0.002〜0.07 ppm $\mathrm{NO}_{2}{ }^{-}-\mathrm{N}$ の超微量が感度 よく定量できた.

上述の抽出をアルカリ性溶液で行ならと水層は透明に なりやすいが，有機溶媒層は透明になりにくく抽出法と しては成功しなかった。しかし，これらが機因となって 水溶液でこのアゾ色素にアルカリを添加す机ばかなりよ く溶解し橙黄色の溶液を生ずる. 波長 $480 \mathrm{~m} \mu$ でその

\footnotetext{
* 東京工業大学分析化学教室 : 東京都目黑区大岡山
}

吸光度を測定して $0.05 \sim 1.0 \mathrm{ppm} \mathrm{NO}_{2}{ }^{-}-\mathrm{N}$ が定量で きる.

$$
2 \text { 抽出 法 }
$$

\section{$2 \cdot 1$ 試 薬}

$\mathrm{GR}$ 試薬: 酒石酸 (特級) $8.9 \mathrm{~g}$, スルファニル酸 (特 級) $1 \mathrm{~g} ， \alpha$-ナフチルアミン（特級） $0.1 \mathrm{~g}$ 学メノ一乳 鉢でそれぞれとまかく砕いてからよくまぜ合わせ，広口 ビン中に保存する.

ブタノール，シクロヘキサノール：いずれも特級品芷 用いた。

塩酸溶液 $(6.0 N)$ : 炭酸ナトリウム標準溶液 $(0.1 N)$ で檩定した。

西硝酸イオンの標準溶液：覀硝酸ナトリウム（特級） $5 \mathrm{~g} / l$ の溶液せつくり, との一定量を過マンガン酸カ リウム標準溶液 $(0.1 N)$ の一定過剩量に加え, 乙の過 剩の過マンガン酸カリウムなヨウ素法で定量して, 西硝 酸ナトリウムの濃度さ定めた。乙れ適当にうすめて $1000 \mathrm{ppm} \mathrm{NO}_{2}{ }^{-}-\mathrm{N}$ の溶液をつくり，これから各種濃 度の標準溶液さつくった。

\section{$\mathbf{2} \cdot \mathbf{2}$ 装 置}

日立 $\mathrm{EPU}-2$ 型分光光度計, $1 \mathrm{~cm}$ セル. 